Im Ergebnis bleibt deshalb festzustellen: Den Herausgebern ist es gelungen, eine Dokumentation der tragenden Grundsätze und wichtigsten Aktivitäten der Vereinten Nationen und ihrer historischen Vorläufer vorzulegen, wie dies in dieser Sorgfalt, Detailgenauigkeit und Übersichtlichkeit in keiner anderen vergleichbaren Publikation nach 1945 erreicht worden ist. Lediglich die Bibliographie des historischen II. Bandes bedarf der Überarbeitung in einer Neuauflage. Auch sollten die Herausgeber darüber nachdenken, ob die WTOGründungsakte nicht in die Dokumentensammlung eingefügt werden kann, ohne den vorgezeichneten Rahmen zu sprengen.

Hermann Weber

\title{
Fiona McConnell
}

\section{The Biodiversity Convention. A Negotiating History}

International Environmental Law and Policy Series, Kluwer Law International, London / The Hague / Boston, 1996, 223 pp., $£ 77.00$

Those with an academic background expecting a clear, dry, and structured analysis of the negotiations and the genesis of the Convention on Biological Diversity signed at the Rio Summit and now having 165 Member States will be deeply disappointed. "The Biodiversity Convention. A Negotiating History" has a totally different approach. The one Fiona McConnell has chosen is not revealed on the cover nor even on the front page but only on the cover page of the book. Hidden from view at first, one can read as a sub-subtitle what the book is all about: "A Personal Account of Negotiating the United Nations Convention on Biological Diversity - and after". What Fiona McConnell does in the 151 pages of text in the book is exactly that: She tells the history of the Convention and beyond until the end of 1995, but with the added touch that her story is based on her personal experiences as a Convention's negotiator. As a civil servant of the UK government at EPINT, the division of the Department of the Environment dealing with international aspects of environmental protection, she was member of the UK delegation during the entire negotiations. That is the reason why she relates the development of the Convention from a rather personal - and British - perspective; this is also the reason why the third part of the book, the early implementation phase of the Convention after the Rio Summit is less fascinating than the first two parts on the pre-negotiations and the negotiations themselves. After the Rio Summit, Fiona McConnell retired from the Civil Service and acted afterwards as a consultant for UNEP, for the German government and for an industry coalition. Although she had first hand informations because of her excellent connections, she was not involved as directly as before.

Her story starts with the pre-negotiations at the $14^{\text {th }}$ Governing Council of UNEP in June 1987 in Nairobi, with the early and cautious attempts to regulate biological diversity on a 
global scale and ends with the second Conference of the Parties to the Convention on Biological Diversity in November 1995 in Jakarta. McConnell narrates not only the "pure" history of the negotiations of the Convention but also relates them to the preparations for the Rio Summit which were taking place in parallel and summarizes the four meetings for the UNCED Preparatory Committee focusing on their relevance to the Convention's negotiations. As she also tells about the relevant political and institutional decisions in the UK like the involvement of the different ministries or the establishment of an Advisory Group on Biological Diversity she is giving a quite holistic picture of the activities from the UK perspective; maybe a too positive picture of the impact of the UK on the negotiations and its efforts in biodiversity preservation. But her ambition is not to be critical and the whole style of her account is a narrative, without any judgement of any of the views and attitudes of the different actors.

The main part of the book on the negotiations of the Convention allows an in-depth insight into the nature and kind of negotiations. It provides a lot of background information one will never find in the official documents, but which is important to understand the genesis of the final text. McConnell tells with distance and certain amusement about the behaviours of the different actors - the most important are described as "dramatis personae" in one of the Annexes - and the substantial and practical deadlocks. For example, when it had been decided after a long debate that the chairmanship of a negotiation session should be determined by vote, UNEP's official ballot box was locked in a storeroom to which no one could find the key. Or she narrates the "childish Anglo-American game" as she calls it between the delegates of the UK and the US sending notes to each other via those of the United Republic of Tanzania who were sitting in between. The book is somewhat anecdotal, but much more than that. It not only provides a history of the key problems during the negotiations and how they were resolved, but also gives an idea of the technical tools of negotiation within the UN system. For example, one learns about the different types of square brackets around negotiation text, like single strategic brackets round the whole draft, contentious brackets with diametrically opposed texts, tactical brackets as trade-off options, alternative brackets, uncertain brackets, waiting brackets, suspicious brackets and weary brackets. She describes in a quite neutral way the different positions of the participating countries to the most sticky points during the negotiations, without, however, explaining the underlying reasoning. But this would require at least another volume.

To sum it up, the book is written in a lively and mostly entertaining manner, reflecting the problems and methods of solutions at the different negotiation sessions. It provides an inside view that one can rarely get. It is slightly biased as it is written from somebody who was deeply involved in the negotiations. The book has ten helpful annexes with key documents from negotiations of the Convention on Biological Diversity as well as the convention's text itself, and a short description of the most important actors.

Gudrun Henne 